\title{
Salt Production Business Potential in Aceh as Capital for the Coastal Communities Welfare
}

\author{
Yety Rochwulaningsih \\ Master and Doctoral Program of History, Faculty of Humanities, \\ Diponegoro University
}

\begin{abstract}
This article aims to identify and analyze small-scale salt production business potential in Aceh as one of the areas of salt production support in Indonesia. It is important to discuss in order to be a good and strategic capital to develop and improve Aceh coastal community welfare, of which the poverty rate is the second highest in Indonesia. By applying observation method, comprehensive interview, and focus group discussion, it can be determined that Aceh factually has the potential of marine and fishery resources including small-scale salt production business sector that can be used as a means to overcome the poverty of coastal communities because this sector provides employment for

Received:

24 Juni 2018

Revised:

1 July 2018

Accepted:

2 July 2018

Corresponding author:

wulan@undip.ac.id $45.59 \%$ productive age population. With quite high production area and small-scale salt production business potential and the number of entrepreneurs of 1,135 people in several regions like Aceh Besar, Pidie, Aceh Utama, East Aceh, etc., it is very rational if the smallscale salt production business becomes one of the gateways to overcome the poverty of coastal communities in Aceh. The development that can be performed is changing the entrepreneurs' mindset to be the entrepreneur that can develop group business or cooperative by the supports of coaching, advocacy, and technology facilities as well as business capital.
\end{abstract}

Keywords: Aceh; Poverty; Small-Scale Salt; Development.

\section{Introduction}

Land plots of 'bleu sira' or 'lancang sira' which are not large and house of productions 'jambo sirai' spread over the coastal area of Aceh: Aceh Besar, Pidie, North Aceh, and East Aceh ${ }^{1}$ is one of the proofs that Aceh has potential to produce salt that is valuable for coastal communities' welfare. ${ }^{2}$ This is confirmed by the expression "no salt, no money", which is often conveyed by the salt farmers during the field study. ${ }^{3}$ An expression describing that salt production has been being important matter for life sustainability of some coastal communities of Aceh as Scott (1983) said that it is subsistence patterns, they just living in mediocre, so a minor problem or disaster can threaten their life. ${ }^{4}$

This paper further examines that salt as one of marine resources in Aceh is important to be considered as one of the economical and potential economic products and can be used as capital

${ }^{1}$ KKP RI dan Badan Pusat Statistik. 2017. "Laporan Akhir Pendataan Garam Tahun 2016".

${ }^{2}$ Yety Rochwulaningsih and Mahendra P. Utama, Tipologi Sosiokultural Petambak Garam di Indonesia. Jilid I. (Semarang: Undip Press, 2013), 45.

${ }^{3}$ M. Huda, "Strategi Adaptasi Masyarakat Pesisir Terhadap Perubahan Lingkungan: Studi Petambak Garam di Desa Losarang, Indramayu dan Desa Pinggir Papas Sumenep." (Ph.D dissertation Universitas Indonesia, 2015).

${ }^{4} J a m e s$ C. Scott, Moral Ekonomi Petani: Pergolakan dan Subsistensi di Asia Tenggara (Jakarta: LP3ES, 1983). 
in developing the communities' welfare improvement especially in coastal area that are always identified as economic limitations even poverty area. Such condition has generally constructed the stereotypes of coastal communities as poor communities. ${ }^{5}$ The field fact to the present shows the poverty rate on the coastal communities relatively high even many of coastal communities living under the standard of living. ${ }^{6}$ Poverty is not only affected by single factor but also several factors of natural, cultural, and structural. ${ }^{7}$

As islands region, Aceh Province has coastline long of 1,660 km and sea area of 15,264.06 $\mathrm{km}^{2}$, while the land area reaches $56,770.81 \mathrm{~km}^{2}$ consisting of land and small islands of 119 islands. Meanwhile, the total area of Exclusive Economic Zone (ZEE) of Aceh is $238,807 \mathrm{~km}^{2}$. This geographical condition is a natural potential of coastal areas and small islands even marine resources that can be used as basic capital for Aceh people development especially for independent coastal communities. To develop the independence on macro scale of the state, there are five things required to realize the Maritime State, namely economic strategy by making marine and fisheries sector as the leading sector and law enforcement in order to secure the marine areas. ${ }^{9}$ At the micro level, of course such of things can also be used as reference by the local government of Aceh. Moreover, the marine and fisheries sector along with agriculture, plantation, and forestry sectors occupy the most important position in the economy of Aceh. These sectors provide employment for $45.59 \%$ of primary productive age population in the province.

However, ironically, the data in 2010 shows Aceh as a province with a relatively high poverty rate of $20.98 \%$ and this is above the national poverty rate of $13.33 \%$. It is placed Aceh as a province with the highest poverty rate in Sumatra Island. ${ }^{10}$ Although in 2017 the poverty rate in Aceh decreased to $16.89 \%$, it was remained higher than the Indonesian national poverty rate which dropped to $10.64 \% .{ }^{11}$ Under these contradictory conditions, it is important to explore and identify the potential of marine resources and even the maritime world of Aceh including the efforts of small scale salt for the greatest benefit of Aceh people progress and prosperity. ${ }^{12}$

A study reported that small scale salt production business has been conducted by coastal communities of Aceh since long ago from generation to generation. The salt farmers learn salt production since childhood, by assisting the parents everyday produce salt and then they perform this activity in everyday life as well as transforming it into the next generation, finally it goes on and sustainable. ${ }^{13}$ Therefore, salt farmers in Aceh face many problems when they are targeted for empowerment programs even corporation of small scale salt production business, because their mindset is still shackled by their traditional economic value. In this case, the empowerment target as well as corporation of small scale salt production business has a chance to succeed when the salt farmers are organized in group of salt farmers with entrepreneur or cooperatives mindset and Village-Owned Enterprise of salt who are willing to join the

\footnotetext{
${ }^{5}$ Novi Dwi Harini, “Dari Miyang Ke Longlenan: Pengaruh Jaringan Sosial Pada Transformasi Masyarakat Nelayan," Komunitas: International Journal of Indonesian Society and Culture Vol. 4 (2) 2012: 178.

${ }^{6}$ Lindawati “Faktort-faktor yang Mempengaruhi Peluang Berusaha dan Kegiatan Ekonomi Rumah Tangga Istri Nelayan Pekerja di Kecamatan Medan Belawan. Jurnal Perencanaan dan Pengembangan Wilayah 3, 1 (2017): 1-8.

${ }^{7}$ Hapsoro, Dody Nurstyo Y. “Analisis Pengaruh Variabel Makroekonomi Regional Terhadap Tingkat Kemiskinan Perkotaan Studi Kasus Empat Kota di Indonesia 2007-2010." Fakultas Ekonomi dan Bisnis Universitas Diponegoro.

${ }^{8}$ Badan Pusat Statistik Provinsi Aceh. Aceh Dalam Angka. Aceh: Badan Pusat Statistik, $2012,1$.

${ }^{9}$ Prakoso Bhairawa Putera, “Perspektif dan Peran Ilmu Pengetahuan dan Teknologi dalam Membangun Kemandirian Bangsa pada Tatanan Negara Maritim“, Inovasi: Jurnal Politik dan Kebijakan 10, 2 (2013): 139.

${ }^{10}$ BPS Aceh, Aceh Dalam Angka, 47.

${ }^{11}$ KKP RI and BPS RI, “Laporan Pendataan", 2.

${ }^{12}$ Yety Rochwulaningsih, "Kajian Struktural Usaha Garam Rakyat di Aceh," Humanika Vol. 18 (2) 2013.

${ }^{13}$ Rochwulaningsih and Utama, Tipologi Petambak Garam, 45 and 50
} 
corporation on the condition that the land is adjacent each other to be integrated easily. Based on the field research, the entrepreneur mindset group is an economic organization in the business sector of salt that can apply several corporation components, although in the implementation has various problems and dynamics. ${ }^{14}$ In this case, the entrepreneur of salt has used the rationality in performing business, although the rationality used is a practical rationality associated with particular purpose of daily orientation. ${ }^{15}$ Correspondingly, Coleman asserts that a person acts on a particular purpose, the purpose is influenced by certain values or choices which are more determined by the intention of optimizing usefulness, or satisfying his necessity and desire. ${ }^{16}$

Similar to other coastal areas in Indonesia, small scale salt production business in Aceh is one of the most important and strategic economic activities for some coastal communities, in addition to capture and aquaculture fisheries. Fishery and marine potential in Aceh in 2016 reached 272,7 thousand tons/year with 16,701 fishing vessels and 64,466 fishermen, while the pond area reached 53.000 ha and from the recent data in 2016, land area addition was occurred. ${ }^{17}$ In contrast to fisheries, small scale salt production business in Aceh to date factually is not contributing significantly to the coastal communities' economy in particular and the people of Aceh in general as well as the local governments both at the district/city or province and central levels.

Aceh does not include the center of small scale salt production business region but the region of national salt production support. The climate in Aceh tends to be wet, while to produce salt with evaporation system as dominating Indonesia today, it needs a dry and hot climate. Aceh has high rate of rainfall and rainy days of $165.5 \mathrm{~mm} / \mathrm{month}$ and 14.8 days/month. On the other hand, low intensity of sun exposure is $43 \%$; while the average of air temperature is relatively stable and the wind speed is also stable of $4.8 \mathrm{~m} / \mathrm{s}$. These causes air humidity in Aceh is high at $81.4 \% .^{18}$ Nevertheless, the small scale salt production business in Aceh remains important to be considered as it is a sustainability support, especially for some coastal communities of the province. Therefore, this paper discusses the creative tactics of Aceh coastal communities for small scale salt production business in the climatological issues, and what possible efforts that can be performed to develop the small scale salt production business in order to contribute in the dynamics of people's economy.

\section{Profile of Small Scale Salt Production Business in Aceh}

Small scale salt production business in Aceh is generally carried out by coastal communities, men and women of both fishermen and non-fishermen households. ${ }^{19}$ There is a segmentation of businessmen, men are more dominating in coarse salt production, while women are more dominating in fine salt/table salt production. ${ }^{20}$ Based on the acknowledgment of small scale salt production business actors in Aceh, although the result of salt production business is not always meet the needs of family living properly, they still pursue a career in salt producing industry and survive from generation to generation by producing salt. Even for fishermen

\footnotetext{
${ }^{14}$ Yety Rochwulaningsih, "Pendekatan Sosiologi Sejarah Pada Komoditas Garam Rakyat: Dari Ekspor Menjadi Impor," Jurnal Paramita 22, 1 (2012): 18

${ }^{15}$ L. Laeyendecker, Tata, Perubahan, dan Ketimpangan: Suatu Pengantar Sejarah Sosiologi. (Jakarta: PT. Gramedia, 1983) 339.

${ }^{16}$ G. Ritzer Sociological Theory. (New York: McGraw-Hill Companies, 2011), 445.

${ }^{17}$ KKP \& BPS RI, "Laporan Pendataan", 7.

${ }^{18}$ BPS Aceh, Aceh Dalam Angka, 2.

${ }^{19}$ Rochwulaningsih, "Kajian Struktural".

${ }^{20}$ Rochwulaningsih and Utama, Tipologi Sosiokultural, 49.
} 
household, when fishermen cannot sail, it can be said that their family's sustainability depend entirely on salt production. Salt farmers who pursue salt production business since their childhood and never become fishermen believe that efforts to produce salt can be used as the main livelihood.

Field data indicate that fluctuation or validation of the number of people doing salt production business in Aceh is very low. For example, in 2012 there were 101 people spread across a number of coastal districts of East Aceh Regency, especially in Julok and Darul Aman Sub-districts, and there were 131 people in 2016. The condition is different in North Aceh Regency, there were 360 people in 2012, but the number decreased to 204 people in 2016, they were spread across Dewantara, Syamtalira Bayu, Lapang, and Seunuddon Sub-districts. It is more ironic in Pidie Regency, based on data from the Department of Marine and Fisheries, there were 15624 people in 2012, but based on the Census of 2016, there were only 300 salt farmers. Based on the last data collection in 2017, the number of salt farmers in Aceh were 1,135 people producing 17,275 ton of salt which was dominated by boiling system in the

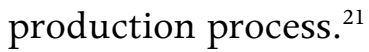

The process of small scale salt production in Aceh can be divided into two types of methods in general, namely by boiling method and solar evaporation method. The boiling method is the production of salt by boiling brine or raw material of salt into fine salt. This method can be applied all the time regardless of the presence or absence of sunlight. Meanwhile, the evaporation method is the production of salt which relies on the process of evaporating seawater in ponds made by farmers by relying on solar evaporation. This method can only be applied in the dry season. ${ }^{22}$

Based on the processed raw material, salt production through boiling method is divided into natural boiling method and concentrate boiling method. The raw material of natural boiling method is brine, while the raw material of concentrate boiling method is coarse salt (krosok). Therefore, the boiling of concentrate is basically a further processing of coarse salt. ${ }^{23}$ Salt farmers in East Aceh only apply the 'natural boiling' method, whereas salt farmers in North Aceh and Pidie apply both methods of boiling. Meanwhile, salt production by solar evaporation method is applied by most salt farmers in North Aceh, Pidie, Bireuen and Aceh Besar.

\section{Boiling Method}

Based on the results of observation and in depth interview, it can be seen that the process of salt production by natural boiling method includes three main tasks that must be done in sequence: preparing media to process seawater into brine, making brine, and boiling brine to produce fine salt.

Media to process seawater into brine is the surface area of flats. Hard or solid flat surface area must be raked (muung-ed) to obtain loose sandy soil. The loose sandy soil is then left to dry under the scorching sunlight around 4 hours (depend on the weather). During the drying process, seawater is doused on the media (soil) around 4-5 times in order to increase the salt content. To save time and energy, small canals are made around the flat to drain seawater from the main canal. After the last watering, the media (soil) is collected and placed in the filtration site. There are 2 ways of filtering. One is done by using a rectangular tub made of board. A container is placed under the tub to accommodate the brine. In Pidie, this kind of tub is called 'jantan'. Another simpler technique, applied by salt farmers in North Aceh, is by

\footnotetext{
${ }^{21}$ KKP \& BPS RI, “Laporan Pendataan”, 14 \& 17.

${ }^{22}$ Rochwulaningsih and Utama, Tipologi Sosiokultural, 191.

${ }^{23}$ Rochwulaningsih and Utama, Tipologi Sosiokultural, 193.
} 
collecting media (soil) to form 2 mounds. Between the two mounds, a basin is made to accommodate the brine.

The media (soil) in the tub and the mound is then doused with seawater. Water that seeps from the media (soil) is called the brine, which is then transferred to the boiling kitchen. The brine is stored in a reservoir by utilizing large plastic barrels or tunnels that are covered with cement on one side. Brine reservoir in the boiling kitchen also serves to reserve the brine supply during the rainy season.

The last stage is boiling. The brine is taken from the reservoir and poured into a large cauldron made from secondhand drums split into two. The cauldron is placed permanently on a stove made of soil. It takes around 5-6 hours to boil seawater to produce salt. The fuel used in general is timber. Sometimes midrib of coconut leaf, coconut fiber and coconut shell are used. Salt farmers get the fuel from their own yards. They often buy timber from merchants.

The above steps basically apply in salt production by concentrate boiling method as well. The difference is that the brine is mixed with coarse salt (krosok) in the last step (boiling) of concentrate boiling method. Salt farmers in Aceh buy coarse salt from Java (Madura) from merchants who act as the raw material suppliers. They take it at Belawan port in Medan.

In the dry season, salt farmers can boil the brine 2-3 times each day. Meanwhile, in the rainy season, most farmers boil once a day or a maximum of two times if they have a stock of brine. From each boiling, $18 \mathrm{~kg}-20 \mathrm{~kg}$ of fine salt can be produced.

\section{Solar Evaporation Method}

Besides in North Aceh, Bireuen and Aceh Besar, preparation of salt by solar evaporation method is done by some salt farmers in Pidie, among others in Ara Village, The flats are more level in this region. Some flat owners come from the city, whereas the farmers are local salt farmers. They usually apply rental or profit sharing system.

Salt production by solar evaporation method requires a larger capital to buy geomembrane used for evaporation base if the farmers want to get good results. As an illustration, in 2012 the price of geomembrane was IDR 20,000 per $\mathrm{m}^{2}$ while a general salt pond (for salt crystallization) was around $2 \times 6$ meters.

The solar evaporation method in Aceh is different from similar method in other areas such as Java, Madura, West Nusa Tenggara and South Sulawesi. The limited area of flats makes farmers in Pidie have no special plot to process the brine before it is put into salt ponds for salt crystallization. Therefore, the production of brine in solar evaporation method in Aceh is carried out more or less similar to the natural boiling method. Salt production by solar evaporation method produces coarse salt (krosok).

Evaporation of brine to produce salt crystals lasts for at least three days. The amount of salt produced will increase if the evaporation is done up to five days. However, farmers often harvest salt three times a day so that they can sell it immediately and reap the benefit of their salt production business.

\section{Distribution and Marketing}

Result of observation and focus group discussion with the small scale salt production businessman in Aceh is the salt of boiling product, both natural and seed can be divided into two types that are bright white and slightly brownish. The brownish salt is produced from the boiling of brine left in the shelter. The color of brownish can also be caused by rust of cauldron during the boiling process. The used cauldrons for boiling are rarely cleaned. The salt produced by the evaporation method can also be divided into two types: the bright white salt and white color mixed with soil. White salt occurs because of the use of sal ponds coated with tarpaulin or plastic which is a geosciolator. Although the white salt is considered better, but the price of both 
salt is not much different. The salt farmer sells the salt with 2,000 IDR. 2,500 IDR - per kg, and becomes higher in the rainy season with IDR 3,000 per kg.

Small scale salt production's product in Aceh is generally without processed, and directly sold to the market. In this case there are several ways, namely (1) the small scale salt production businessmen/salt farmers sell it directly to the consumers in the traditional market, (2) the small scale salt production businessmen sell salt to the collecting merchant in the salt location of traders but some are exchanged for daily needs to the trader, (3) the small scale salt production businessmen sell to the collecting merchant who visits the salt-making site. Almost all traded salt products are not experiencing further process of leaching for hard, iodized, and packed salt. At least every 3-5 days the salt merchant comes to the boiling kitchen to buy and take salt which they generally buy it in cash and some even supply raw materials and special fuel for the boiledsalt farmer.

\section{Mapping on Problem and Development}

Besides the climatological problem, quite a lot of problems experienced by salt farmers in Aceh related to the technology, infrastructure, institutional and land that become an important tool in the process of small scale salt production business. Some of those problems will be mentioned here, with a purpose that we will be able to discuss further. If the problem is overcame, then it will support the effort to develop small scale salt production business in Aceh which then can become a medium in increasing salt farmers income and change the people's economy dramatically.

First, the farmers in Aceh, both in East Aceh, North Aceh, Pidie, Bireuen, Aceh Besar sometimes face the problem of technology limitation (only few of them who can use geosciolator), and flooding in the pond and boiling kitchen during the high tide and heavy rain. It is important to facilitate the use of geosciolator and the program to raise the soil in the location of the boiling kitchen in mass scale. Another option is to elevate the main canal embankment so that the water overflow does not directly enter the pond and boiling kitchen when the tide is high.

Second, salt farmers in Aceh generally find it difficult to store salt, mainly when the produce is abundant. Limited boiling kitchen space to be shared for furnace, salt storage, and brine storage, fuel wood, and media soil supply. Boiling kitchen is generally unhealthy because the air circulation is not smooth, the dust easily enters and pollutes the processed/boiling salt. Boiling kitchen should be designed to make a furnace or hygienic boiling kitchen equipped with a chimney so that the smoke during the boiling process is out properly and the dust is uneasy to enter and the farmer's health remains good.

Third, the salt price is very volatile. During the dry season, when the yields are abundant, the salt farmers who are depressed for daily needs helpless to face the collecting merchants that suppress the price. Conversely, if it cannot produce then the salt price is high and it is very difficult to be accessed by farmers. Give proper facilitation and advocacy on the institution that run the role and function of small scale salt cooperatives (Koperasi Garam), if it can be performed properly by various parties who care and synergize it will be a way for the effort to increase salt farmer's income and welfare. ${ }^{24}$

Fourth, the salt produced by farmers is only absorbed in the consumption market and limited to grocery store and traditional market through the collecting and traveling traders. Local salt has not been able to compete with the salt from other regions mainly the salt supplied outside from Aceh. Aceh's salt has not been able to meet the requirements for salt consumption,

${ }^{24}$ Yety Rochwulaningsih, “Tata Niaga Garam Rakyat Dalam Kajian Struktural”, Citra Lekha 17, 1 (2013): 61. 
the three of the most important requirements are impurity, iodine content and packaging. This issue opens the opportunity for developing salt processing business. Using that way, the salt from farmers can be processed to increase the added value, such as leaching, iodine and packaging, so that the products become qualified according to national standard (SNI) with the increasing selling price.

Fifth, salt flats in the areas hit by tsunami are severely damaged and cannot be used optimally to produce salt. Therefore, the still-irrigated ponds need to be revitalized and the Government is obliged to take the largest part to revitalize the damaged salt flatss through clear, transparent and accountable strategic action programs. Accompanying the revitalization of this salt flats is a redistribution program of law enforcement ponds given to salt farmers who produce salt.

\section{Conclusion}

Looking at the potential of small scale salt production business in Aceh is very interesting, because it has three important aspects of an economic business, namely the availability of land, human resources as the business actor and market. The main problem is that this sector has not been seen by the public or the government as an important and strategic sector to be worked on and used as media to increase the income and economic improvement of business actor and coastal society in Aceh. Whereas, small scale salt production empirically proves to be the main source of living and life of some coastal society in Aceh. Therefore, it is time to conduct exploration and potency identifying, this business opportunity and challenges to further integrate it into coastal society development action program as well as the large Aceh society development.

This study also formulates that the development of small scale salt production business in Aceh can be conducted through several ways both institutional and technological ways in the sense of soft and hard ones. The institution is related to how we build the idea of salt farmers who have the orientation of entrepreneurs, then it requires the organization of business groups or cooperatives and Gampong Owned Enterprises as a medium to conduct the learning process of Joint business. The used technology of salt production in the small scale salt production in Aceh consists of solar, evaporation, and boiling. In the solar evaporation, the important point is making arrangements or lay out of land that can perform the production process effectively and efficiently accompanied by the rehabilitation of dikes for the production area. The boiling method is very important in the revitalization and development of production houses that support the achievement of more hygienic production and healthful business actor.

\section{References}

Badan Pusat Statistik Provinsi Aceh. Aceh Dalam Angka. Aceh: Badan Pusat Statistik, 2016. Hapsoro, Dody and Nurstyo Y. Analisis Pengaruh Variabel Makroekonomi Regional Terhadap Tingkat Kemiskinan Perkotaan Studi Kasus Empat Kota di Indonesia 2007-2010. Fakultas Ekonomi dan Bisnis Universitas Diponegoro, 2013.

Harini, Novi Dwi. "Dari Miyang Ke Longlenan: Pengaruh Jaringan Sosial Pada Transformasi." Masyarakat Nelayan. Jurnal Komunitas 4, 2 (2012): 178-190.

Huda M. "Strategi Adaptasi Masyarakat Pesisir Terhadap Perubahan Lingkungan: Studi Petambak Garam di Desa Losarang, Indramayu dan Desa Pinggir Papas Sumenep." Ph.D dissertation Universitas Indonesia, 2015.

Kinseng, R. A. Diatin I, Fahrudin A. "Dampak Program Bina Desa Terhadap Perilaku Masyarakat di Desa Binaan." Buletin Ekonomi Perikanan 2 (3). 
KKP RI dan Badan Pusat Statistik. 2017. "Laporan Akhir Pendataan Garam Tahun 2016".

Laeyendecker L. Tata, Perubahan, dan Ketimpangan: Suatu Pengantar Sejarah Sosiologi. Jakarta: PT. Gramedia, 1983.

Lindawati. “Faktort-faktor yang Mempengaruhi Peluang Berusaha dan Kegiatan Ekonomi Rumah Tangga Istri Nelayan Pekerja di Kecamatan Medan Belawan." Jurnal Perencanaan dan Pengembangan Wilayah 3, 1 (2007): 1-8.

Putera, Prakoso Bhairawa. "Perspektif dan Peran Ilmu Pengetahuan dan Teknologi dalam Membangun Kemandirian Bangsa pada Tatanan Negara Maritim." Inovasi: Jurnal Politik dan Kebijakan 10, 2 (2013): 139. 252.

Ritzer, G. Sociological Theory. New York: McGraw-Hill Companies, 2011.

Rochwulaningsih, Yety and Utama, Mahendra. Tipologi Sosiokultural Petambak Garam di Indonesia. Jilid I. Semarang: Undip Press, 2013.

Rochwulaningsih, Yety. "Pendekatan Sosiologi Sejarah Pada Komoditas Garam Rakyat: Dari Ekspor Menjadi Impor." Jurnal Paramita 22, 1 (2012): 14-24.

Rochwulaningsih, Yety. "Kajian Struktural Usaha Garam Rakyat di Aceh." Humanika 18, 2 (2013).

Rochwulaningsih, Yety. “Tata Niaga Garam Rakyat Dalam Kajian Struktural." Citra Lekha 17, 1 (2013): 59-66.

Scott, James. Moral Ekonomi Petani: Pergolakan dan Subsistensi di Asia Tenggara. Jakarta: LP3ES, 1983. 